\title{
INTEGRASI PENDIDIKAN KARAKTER DALAM PEMBELAJARAN SEJARAH KELAS XI SMU MUHAMMADYAH DI KOTA MATARAM
}

\author{
Rosada \\ Pendidikan Sejarah, Universitas Muhammadiyah Mataram, Ros ada84@yahoo.co.id
}

INFO ARTIKEL
RiwayatArtikel:
Diterima: 03-11-2016
Disetujui: 04-12-2016

Kata Kunci:

1. Pendidikan karakter

2. Pembelajaran sejarah

\begin{abstract}
ABSTRAK
Abstrak: Penelitian ini bertujuan untuk menemukan data terkait bagaimana integrasi pendidikan karakter pada pembelajaran sejarah yang dilakukan guru di kelas XI di SMA Muhammadiyah Mataram. Penelitian ini merupakan penelitian kualitatif deskriptif. Subjek penelitian ini yaitu Integrasi Pendidikan Karakter dalam Pembelajaran Sejarah Kelas XI SMU Muhammadyah di Kota Mataram. Peneliti bertindak sebagai keyinstrument. Data dikumpulkan dari wawancara, observasi dan dokumntasi. Teknik analisis data menggunakan analisis interaktif. Hasil penilitian yaitu bahwa integrasi pendidikan karakter dalam pembelajaran sejarah yang dilakukan guru di kelas XI SMA Muhammadiyah Mataram dengan cara: menciptakan lingkungan belajar yang kondusif, Memberikan pendidikan karakter secara eksplisit, sistematis dan berkesinambunga, Metode pengajaran yang memperhatikan keunikan masing-masing anak, Membangun hubungan yang suportive dan penuh perhatian di kelas dan seluruh sekolah harus berkarakteristik aman, Model (contoh) prilaku positif, Menciptakan peluang bagi siswa untuk menjadi aktif dan penuh makna termasuk dalam kehidupan di kelas dan sekolah, Mengajarkan keterampilan sosial dan emosional secara esensial, Melibatkan siswa dalam wacana moral, isu moral, dan membuat tugas pembelajaran yang penuh makna dan relevan untuk siswa.

This study aims to find data related to how the integration of character education on learning history conducted by teachers in grade XI in SMA Muhammadiyah Mataram. This research is descriptive qualitative research. The subject of this research is the Integration of Character Education in Learning History of Class XI SMU Muhammadiyah in Mataram City. The researcher acts as a keyinstrument. Data were collected from interviews, observation and documentation. Data analysis techniques use interactive analysis. The result of research is that the integration of character education in teaching history done by teacher in grade XI SMA Muhammadiyah Mataram by: creating a conducive learning environment, Providing character education explicitly, systematically and sustainable, Teaching methods that pay attention to the uniqueness of each child, the suportive and attentive in the classroom and the whole school should be characterized as safe, Models (examples) of positive behaviors, Creating opportunities for students to be active and meaningful including in life in the classroom and school, Essentially taught social and emotional skills, Involving students in moral discourse, moral issues, and create meaningful and relevant learning tasks for students.
\end{abstract}

\section{A. LATAR BELAKANG}

Tujuan pendidikan mengalami perkembangan dari tahun ke tahun. Pada awalnya, pendidikan hanya berorientasi pada pribadi subjek peserta didik. Namun lambat laun makna pendidikan berkembang menjadi pengembagan potensi. Pengembangan potensi yang dimaksud yakni pengembangan secara jasmani dan rohani. Pengembangan potensi secara jasmani dan rohani yang dimaksud tiada lain agar peserta didik memiliki kepribadian dan keterampilan yang didasari oleh kecerdasan spritual dan akhlak mulia. Dengan kata lain pendidikan bertujuan untuk mengembangkan pertumbuhan kepribadian seseorang. Noeng Muhajir (2000: 15-20) mengatakan pendidikan berfungsi untuk menumbuh kembangkan nilai-nilai insani dan illahi pada subjek didik dan satuan sosial masyarakat serta meningkatkan kemampuan kerja produktif pada subjek didik.

Tujuan pendidikan yang tercantum dalam undang-undang No 20 tahun 2003 tentang sistim pendidikan nasional berfungsi untuk mengembangkan kemampuan dan membentuk watak serta peradaban bangsa bermartabat dalam rangka mencerdaskan kehidupan bangsa, pendidikan nasional bertujuan untuk 
mengembangkan potensi peserta didik menjadi insan beriman dan bertakwa kepada tuhan yang maha esa, berakhlak mulia, sehat, berilmu, cakap, kreatif, mandiri, dan menjadi warga negara demokratis serta bertanggung jawab.

Pendidikan adalah usaha sadar dan sistimatis yang dilakukan oleh orang-orang yang diserahi tanggung jawab untuk mempengaruhi peserta didik agar mempunyai sifat dan tabiat sesuai dengan cita-cita pendidikan. Pendidikan merupakan proses bantuan dan pertolongan yang diberikan oleh pendidik kepada peserta didik atas pertumbuhan jasmani dan perkembangan rohaninya secara optimal.

Namun dewasa ini dunia pendidikan semakin terpuruk karena dianggap gagal mendidik generasi muda Indonesia. Porsi kegagalan terbesar di dunia pendidikan dewasa ini adalah terkait model pembelajaran yang diterapkan selama ini. Tidak dapat dipungkiri bahwa model pembelajaran yang diterapkan selama ini adalah pembelajaran yang hanya menyuguhkan ingatan dan hafalan, terutama pembelajaran Sejarah. Materi Pelajaran sejarah memang banyak, terfokus pada kisah, cerita, tentang kejadian pada masa lampo, lalu bagaimana guru mampu mendisain pembelajaran agar bisa menarik dan mampu memotivasi siswa serta mampu mengintegrasikan pendidikan karakter. Sehingga pelajaran tidak hanya dilaksanakan karena akan menghadapi ujian saja, setelah itu hilang begitu saja, akan tetapi memahami apa seharusnya yang mampu diambil dari pelajaran tersebut yang kemudian diterapkan dalam kehidupan sehari-hari.

Dunia pendidikan seperti kehilangan perannya. Hal ini dapat dilihat dari adanaya prilaku menyimpang yang dilakukan baik itu oleh pengelola, pengurus, maupun siswa misalnya ketidakjujuran dalam pendidikan kasus bertindak curang baik berupa tindakan mencontek, mencontoh pekerjaan teman atau mencontoh dari buku pelajaran ketika ujian seolah-olah itu merupakan pekerjaan sehari-hari. Jalan keluar yang banyak dikemukakan adalah pendidikan. Pendidikan dianggap sebagai alternatif yang bersifat preventif karena pendidikan

Selain itu lingkungan sangat mempengaruhi tujuan pendidikan apalagi untuk membentuk karakter siswa, terutama di wilayah kota khususnya kota mataram. Mataram memang diidentikkan dengan kota religius aman dan berbudaya, tetapi mewujudkan semua itu membutuhkan usaha keras agar tercapai tujuan bersama. Walaupun program pembentukan karakter sudah diprogramkan misalkan saja tentang etika dan sopan santun serta busana yang sopan, mulai diprogramkan agar terbiasa dari hal kecil hingga yang besar, akan tetapi itu tidak menjadi jaminan semuanya teratasi kecuali dari semua pihak bekerjasama untuk membentuk karakter siswa, misalkan dari lingkungan sekolah dengan cara mengintegrasikan ke dalam pembelajaran, keluarga, media sosial, tempat umum dan lain sebagainya sehingga dimanapun mereka terbiasa dengan hal tersebut sehingga itulah yang akan membentuk karakter siswa.

$$
\text { Dalam pembelajaran misalkan dengan }
$$

mengintegrasikan ke dalam pembelajaran sehingga mampu membentuk karakter siswa. Pembentukan karakter harus optimal melalui berbagai hal sehingga hasilnya maksimal. Mengintegrasikan ke dalam pembelajaran seharusnya tidak terfokus pada pelajaran agama atau pendidikan moral akan tetapi semua pelajaran, terutama pelajaran sejarah. Usaha yang dilakukan dalam hal tersebut dengan mengintegrasikannya ke dalam pembelajaran sejarah, tehnik yang dilakukan dengan menitik beratkan kepada aspek afektif sehingga, siswa mampu mengaplikasikannya ke dalam kehidupan seharihari. Pendidikan karakter di dalam kurikulum memang tidak tercantum akan tetapi dari dulu sudah teraplikasikan ke dalam kurikulum. Kurikulum yang dimaksud adalah hidden kurikulum.

Dipaparkan (Dakir, 2004:7) hidden kurikulum berarti bahwa yang tersembunyi, artinya tidak dapat hilang, jadi kurikulum tersembunyi ini tidak direncanakan, tidak diprogramkan dan tidak dirancang tetapi mempunyai pengaruh besar secara langsung maupun tidak langsung terhadap out put dari proses belajar mengajar.

Kurikulum tersembunyi yakni dalam proses belajar mengajar guru tidak hanya menyampaikan materi akan tetapi harus memberikan contoh dari apa yang sudah dipelajari sehingga siswa belajar memahami dan memaknai apa yang dipelajari dari materi yang diajarkan. Dengan mempertimbangkan bahwa pertumbuha individu 
dalam perkembangan moral merupakan "proses" perkembangan, akan metode pendidikan hendaknya tidak dengan cara menasehati, menaati aturan, dengan memberikan hukuman dan ganjaran, namun metode yang membentuk struktur kognitif yaitu dengan menciptakan stimulasi kognitif dengan mengembangkan empati, yaitu dengan menstimulasi individu untuk menempatkan diri di tempat orang lain dengan berperan sebagai orang lain.

Oleh sebab itu dalam penelitian ini peneliti akan mengangkat dan menggali data terkait Bagaimana Integrasi Pendidikan Karakter pada Pembelajaran Sejarah yang Dilakukan Guru di Kelas XI di SMA Muhammadiyah Mataram?

\section{B. METODE PENELITIAN}

\section{Jenis Penelitian}

Jenis penelitian ini merupakan penelitian kualitatif deskriptif yaitu memaparkan semua fenomena yang terjadi selama dalam setting penelitian. Alasan menggunakan pendekatan ini bertujuan untuk menggambarkan keadaan suatu fenomenayang terjadi, dan berusaha memamparkan data sebagaimana adanya tentang bagaimana Integrasi Pendidikan Karakter dalam Pembelajaran Sejarah Kelas XI SMU Muhammadyah di Kota Mataram

\section{Subjek dan Objek Penelitian}

Penelitian ini dilakukan secara menyeluruh tentang bagaimana Integrasi Pendidikan Karakter dalam Pembelajaran Sejarah Kelas XI SMU Muhammadyah di Kota Mataram. Tujuanya adalah untuk menggali data yang dibutuhkan dalam rumusan masalah yang telah dipaparkan. Subjek penelitian diambil dengan cara memilah data sesuai dengan yang diinginkan.

\section{Teknik dan Instrumen Pengumpulan Data}

Peneliti bertindak sebagai key instrument, karena peneliti sebagai pengumpul data yang utama. Key instrument kapasitasnya bertindak sebagai perencana, pelaksana pengumpulan data di lapangan, sekaligus sebagai analisis dan pelapor hasil penelitian. Sumber data berupa perkataan atau perbuatan dari informan yang mengarah pada fokus penelitian.

\section{Keabsahan Data}

Terdapat beberapa teknik uji keabsahan data yang dapat dilakukan dalam penelitian yang disesuaikan dengan kriteria dan teknik pemeriksaan yaitu dengan cara memperpanjang waktu penelitian dan menguji dengan teknik triangulasi. Teknik triangulasi dimaksudkan untuk memperoleh derajat kepercayaan yang tinggi. Triangulasi merupakan proses menemukan kesimpulan dengan mengecekulang dari berbagai sudut pandang.

Validitas data dimaksudkan untuk membuktikan apakah hasil pengamatan yang diperoleh tentang manfaat menggunakan bagaimana program. Untuk mengetahui penjelasan yang diberikan informan tersebut sesuai dengan keadaan sebenarnya ada atau tidak terjadi. Pembuktian menggunakan cek silangdata, baik antara dinas sosial dengan masyarakat di lapangan. Selain itu dilakukan pengkajian kembali tentang instrumen yang digunakan, pertanyaanyang terkaitlangsung dengan penelusuran data pemeberdayaan keterbelakangan mental oleh dinas social

\section{TeknikAnalisis Data}

Langkah selanjutnya, setelahdata lapangan terkumpul, peneliti menganalisis data. Untuk menghindari kekeliruan dan penumpukan data, sehingga dapat mengakibatkan tereduksinya validitas dan kreadibilitas data.Analisis yang dilakukan dengan menggunakanan alisis interaktif, terdiri dari tiga alur yang berjalan secara simultan yaitu reduksi data, penyajian data, dan penarikan kesimpulan. Menurut (Matthew, 1992: 16) reduksi data adalah proses pemilihan, pemusatan perhatian pada penyederhanaan, pengabstrakan, dan transformasi data kasar yang muncul dari catatan-catatantertulis di lapangan.

Analisi dilakukan pada waktu berada di lokasi penelitian dan setelah peneliti meninggalkan lokasi penelitian. Data dari lapangan dianalisis dengan cara direduksi, dirangkum, dan difokuskan, pada hal yang penting dicari,tema dan hubungan yang sering terjadi, sehingga kesimpulan itu akan lebih mendasar. Jadi kesimpulan yang dibuat,harus selalu diverifikasi selama penelitian berlangsung.

Data yang sudah terkumpul dari hasil wawancara, observasi, dan dokumentasi, kemudian dianalisis berdasarkan model analisis intreaktif yang dikembangkan oleh Miles dan Huberman (1992: 15-20). Ada 4 komponen yang dilakukan dengan model ini, yaitu pengumpulan, 
reduksi,display dan penarikan verifikasi. Dari keempat komponen ini saling berintreaksi dan membentuk suatu siklus analisis penelitian.

a. Pengumpulan data

Data yang berhasil dikumpulkan melalui wawancara, observasi dan dokumentasi dicatat dalam bentuk catatan lapangan (fieldnotes). Catatan lapangan berisi apa yang ditemukan oleh informan tentang tafsiran peneliti terhadap informasi yang diberikan oleh responden.

\section{b. Reduksi data}

Reduksi data diperlukan karena banyaknya data dari masing-masing informan yang dianggap tidak relevan dengan fokus penelitian, sehingga perlu dibuang atau dikurangi. Reduksi data dilakukan dengan memilih hal pokok yang sesuai dengan fokus penelitian, maka akan memberikan gambaran yang lebih tajam.

\section{c. Display data}

Data yang sudah direduksi dapat disajikan dalam bentuk tabel, gambar atau tulisan yang telah tersusun secara sistimatis agar data bisa dikuasai dan dipahami, selanjutnya lebih mudah untuk ditarik kesimpulan

\section{d. Verifikasi}

Penarikan kesimpulan sudah dilakukan sejak awal penelitian berlangsung. Setiap perolehan data dianalisis dan disimpulkan walaupun masih kabur maknanya, tetapi akan semakin jelas dengan semakin banyaknya data yang diperoleh untuk mendukung verifikasi.

Menunjukkan bahwa dalam menganalisis data, pada penelitian ini akan melalui beberapa proses, yaitu mulai dari pengumpulan data sesuai dengan teknik yang ditentukan. Selama proses pengumpulan data tersebut juga dilakukan reduksi data untuk menajamkan, menggolongkan, mengarahkan, mengorganisasi, sehingga dapat dibuat kesimpulan. Selanjutnya disajikan data dalam bentuk yang sistimatik kemudian diakhiri dengan penarikan kesimpulan.

\section{HASIL DAN PEMBAHASAN}
1. Integrasi Pendidikan
Karakter Dalam Pembelajaran Sejarah Yang Dilakukan Guru di Kelas XI SMA Muhammadiyah Mataram.

Pelaksanaan pendidikan karakter dalam pembelajaran sejarah tidak bisa terbentuk secara instan namun membutuhkan proses. Proses pembelajaran sejarah yang dilakukan oleh guru kelas XI SMA Muhammadiyah Mataram sesuai dengan silabus dan RPP dan dalam penyusunannya sudah mulai mengintegrasikan pendidikan karakter di dalamnya. Salah satunya dengan menerapkan model pembelajaran yang melibatkan partisipasi aktif siswa, dapat meningkatkan motivasi siswa karena seluruh dimensi manusia terlibat secara aktif salah satu contoh metode yang digunakan guru yaitu scrambled group diskusi. Hal ini dilakukan selain untuk mengaktifkan siswa, metode ini mampu melatih kerjasama dan tanggungjawab terhadap siswa. Sehingga dalam proses pembelajaran sejarah sudah terdapat kompetensi inti tentang bagaimana menghayati dan mengamalkan prilaku jujur, disiplain, tanggung jawab, peduli (gotong royong) damai, santun, responsif dan pro aktif dan menunjukkan sikap dari sebagian solusi atas berbagai masalah dalam berinteraksi secara efektif dengan lingkungan sosial dan alam menempatkan diri sebagai cerminan bangsa dalam pergaulan dunia.

Integrasi pendidikan karakter dalam pembelajaran sejarah yang dilakukan oleh guru kelas XI di SMA Muhammadiyah Mataram dapat dijelaskan secara rinci sebagai berikut:

a. Menciptakan lingkungan belajar yang kondusif sehingga anak dapat belajar dengan efektif di dalam suasana yang memberikan rasa aman, penghargaan, tanpa ancaman, dan memberikan semangat.

b. Memberikan pendidikan karakter secara eksplisit, sistematis dan berkesinambungan dengan melibatkan aspek knowing the good, living the good, dan acting the good. Terkadang guru memberikan materi hanya sekedar tansfer of knowladge bukan memberikan ilmu agar mereka tau dan paham apa yang harus diaplikasikan dalam kehidupan sehari-hari dengan ilmu tersebut. Metode pengajaran yang memperhatikan keunikan msing-masing anak yaitu menerapkan kurikulum yang melibatkan juga 9 aspek kecerdasan manusia. Memahami siswa salah satu metode yang harus terus diperhatikan guru, karena di sekolah merupakan wadah untuk menggali siswa memiliki skill apa, kemudian bisa dikembangkan. Siswa dituntut tidak hanya cerdas dari aspek kognitif tetapi juga aspek afektif.

c. Membangun hubungan yang suportive dan penuh perhatian di kelas dan seluruh sekolah harus 
berkarakteristik aman serta saling percaya, hormat dan perhatian kepada kesejahteraan lainnya

d. Model (contoh) prilaku positif. Bagian terpenting dari penataan lingkungan yang suportive dan penuh perhatian di kelas adalah teladan prilaku penuh perhatian di kelas dan penghargaan dari guru danganinteraksinya dengan siswa. Contoh prilaku positif tersebut terus menerus dilakukan tidak harus dengan yang besar dengan yang kecil juga, seperti memberikan punisment atau reward kepada siswa yang mengamalkan pendidikan karakter, seperti berprilaku jujur saja sudah diberikan apresiasi, begitu sebaliknya berbohongpun diberikan punisment.

e. Menciptakan peluang bagi siswa untuk menjadi aktif dan penuh makna termasuk dalam kehidupan di kelas dan sekolah. Sekolah harus menjadi lingkungan yang lebih demokratis sekaligus tempat bagi siswa untuk membuat keputusan dan tindakan, serta untuk merefleksi atas hasil tindakannya.

f. Mengajarkan keterampilan sosial dan emosional secara esensial. Bagian terpenting dari peningkatan perkembangan positif siswa termasuk pengajaran langsung keterampilan sosial-emosional, seperti mendengarkan ketika orang lain bicara, mengenali dan memenej emosi, menghargai perbedaan, dan menyelesaikan konflik melalui cara lemah lembut yang menghargai kebutuhan(kepentingan) masing-masing.

g. Melibatkan siswa dalam wacana moral, isu moral adalah esensi pendidikan anak untuk menjadi prososial, moral manusia.

h. Membuat tugas pembelajaran yang penuh makna dan relevan untuk siswa, tolak ukur yang sesungguhnya dari kesuksesan sekolah termasuk pendidikan semua siswa untuk mewujudkan seluruh potensi mereka dengan membantu mereka mengembangkan bakat khusus dan kemampuan mereka, dan dengan membangkitkan pertumbuhan intelektual, etika, dan emosi mereka.

\section{SIMPULAN DAN SARAN}

Integrasi Pendidikan Karakter Dalam Pembelajaran Sejarah Yang Dilakukan Guru di Kelas XI SMA Muhammadiyah Mataramdengan cara: Menciptakan lingkungan belajar yang kondusif, Memberikan pendidikan karakter secara eksplisit, sistematis dan berkesinambunga, Metode pengajaran yang memperhatikan keunikan msingmasing anak yaitu menerapkan kurikulum yang melibatkan juga 9 aspek kecerdasan manusia, Membangun hubungan yang suportive dan penuh perhatian di kelas dan seluruh sekolah harus berkarakteristik aman serta saling percaya, hormat dan perhatian kepada kesejahteraan lainnya, Model (contoh) prilaku positif, Menciptakan peluang bagi siswa untuk m enjadi aktif dan penuh makna termasuk dalam kehidupan di kelas dan sekolah, Mengajarkan keterampilan sosial dan emosional secara esensial, Melibatkan siswa dalam wacana moral, isu moral, Membuat tugas pembelajaran yang penuh makna dan relevan untuk siswa.

\section{DAFTAR RUJUKAN}

Aqib, Zainal dan Sujak.2011. panduan dan aplikasi pendidikan karakter.BandungYrama Widya

Bertens, K.(1993). Etika.Cet. Ke-8. Jakarta: Gramedia

Cristopher Drake.(2007). Pentingnya lingkungan berbasis nilai. Journal of moral educations Trust. London: London University

Darmiayati zuchdi.(2008). Humanisasi Pendidikan, Jakarta : Bumi Aksara

Doni kusuma,A.(2007). Pendidikan Karakter, Jakarta: Grasindo

Dakir. (2004). Perencanaan dan pengembangan kurikulum. Buku pegangan kuliah cet. Ke -I. Jakarta: PT.Rineka Cipta

Slamet .(2008). Desentralisasi pendidikan di Indonesia, educations planing management specialist team leader of fackage 2 decentralized basict eductions project. ADB Loan No.1863-INO. Pengembangan pendidikan karakter siswa oleh sekolah jakarata: departemen pendidikan Indonesia

Lickona, T. (1992). Educating for character, how our schools can teach respect. respect and responsibility. New York: Bantam Books.

Sulistyowati, Endah. 2012.Implementasi Kurikulum PendidikanKarakter. Yogyakarta: PT CitraAjiParama

Rohmat,M.(2004). Mengartikulasikan Pendidikan Nilai, Bandung: 